\title{
Aquifer Vulnerability using Recharge, Depth to Groundwater, Soil Type and Slope to classify the Vadose Zone (Molototsi and Middle Letaba Quaternary Catchments, Limpopo Province, South Africa)
}

\author{
Makonto, O. T. ${ }^{1,2}$ and Dippenaar, M. A. ${ }^{1}$ \\ ${ }^{1}$ Engineering Geology and Hydrogeology, Department of Geology, University of Pretoria, Private Bag X20, Hatfield, 0028, \\ Pretoria, Republic of South Africa \\ madip@up.ac.za / madippenaar@gmail.com / www.up.ac.za/geology
}

$+27(0) 124203117$

${ }^{2}$ Council for Geoscience, Water Geoscience Business Unit, Private Bag X112, Pretoria, Republic of South Africa

olma@webmail.co.za / olma.makonto@gmail.com / omakonto@geoscience.org.za / www.geoscience.org.za

$+27(0) 128411175$

\begin{abstract}
The aquifer vulnerability of the Molototsi (B81G) and Middle Letaba (B82D) quaternary catchments was assessed to determine the influence of the vadose zone on the groundwater regime. The aquifer vulnerability was assessed by developing a new method, which evaluates the vadose zone as a pathway for pollutants by using the following four parameters: Recharge, Depth to water table, Soil type (saturated vertical hydraulic conductivity) and Slope (RDSS). Recharge was estimated using the Chloride-mass balance method and the depth to the water table was measured in the field using dipmeter. The seepage behaviour (soil type) was determined as hydraulic conductivity from in-situ infiltration and percolation testing (SABS 0252-2:1993 and double ring infiltrometer). The slopes were determined with the digital elevation method using ArcGIS software. The four parameters were overlaid using Weighted Sum, Weighted Overlay and Raster Calculator to produce the vulnerability map. Different weightings were attributed in the methods and the best selected. The results obtained indicated high vulnerability on the lower and upper parts of both catchments. The benefits of the method described are (a) the easy quantification of the parameters through fairly simple methods and (b) the exclusion of arbitrary index values.
\end{abstract}

Keywords: Vadose zone, aquifer vulnerability, Molototsi, Middle Letaba.

\section{Introduction}

The vadose zone is the portion of the geological profile above the groundwater (phreatic) surface (Poehls and Smith, 2009). It is often called the 'unsaturated zone' or 'zone of aeration'. According to Babiker et al., (2005) vulnerability assessment has been recognised for its ability to delineate areas that are more likely than others to become contaminated as a result of anthropogenic activities. Once the areas susceptible to contamination are identified, it can be targeted for careful land-use planning, intensive monitoring and prevention of groundwater contamination. 
The objectives of this study were to assess the vadose zone as a pathway for contamination from surface (vulnerability) and to deduce a method for quantifying aquifer vulnerability based on relevant parameters.

\section{Materials and Methods}

\section{$\underline{\text { Study Area }}$}

The Molototsi and Middle Letaba quaternary catchments form part of the Luvuvhu/ Letaba Water Management Area (WMA2) located in Limpopo Province of South Africa (Figure 1). Both catchments are characterised by warm, frost free and subtropical climate with summer rainfall. The mean annual temperature ranges from $18^{\circ} \mathrm{C}$ to more than $28^{\circ} \mathrm{C}$, with an average of $25.5^{\circ} \mathrm{C}$ (DWAF, 2004). The rainfall is seasonal and occurs mainly during summer months, i.e. October to March (DWAF, 2003). The peak rainfall months are January and February with the dry season beginning in April with rainfall decreasing dramatically and with June being the driest month of the year. The catchments are characterised by low rainfall and high potential evaporation figures of $400-600 \mathrm{~mm}$ and 2100 -2 $200 \mathrm{~mm}$ per annum respectively (Nyabeze et al., 2007).

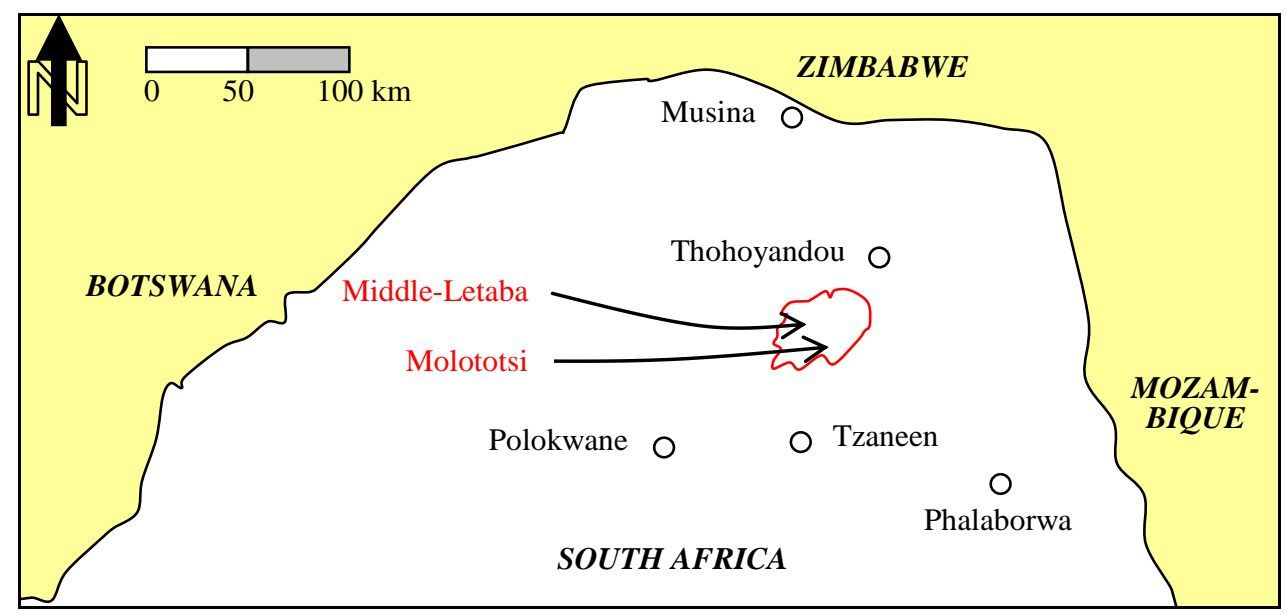

Figure 1. Locality of the Molototsi and Middle Letaba quaternary catchments (Dippenaar et al. 2010).

The area is characterised by hills with steep to gentle slopes. Soils of study area consist predominantly of medium clay loam to sandy clay. Generally, the Pietersburg and Giyani greenstone belts are the dominant features within the granite gneiss terrain of the northern Kaapvaal Craton. Both the Giyani and Pietersburg greenstone belts are 
surrounded mainly by granitoid gneisses and plutons of massive late-stage K-rich granites (Kröner et al., 2000). In both belts the mafic rocks dominate over ultramafics, with felsic and sedimentary rocks playing subordinate role.

Groundwater is extensively used as a source of water supply for rural communities in both catchments. There are relatively large groundwater resources in these catchments, estimated to be about $30 \%$ of the utilisation in the subareas. The contribution of groundwater to the available water in Middle Letaba and Molototsi quaternary catchments is estimated to be about 9 and 12 million $\mathrm{m}^{3} / \mathrm{a}$ respectively. Groundwater is also used to supplement irrigation during times of drought in both catchments (DWAF, 2004). Groundwater abstraction takes place close to the rivers and probably has a direct impact on the surface water flow, as has been addressed in Dippenaar et al. (2009). Moderate to good yields of $>5 \mathrm{\ell} / \mathrm{s}$ are found in both catchments (DWAF, 2003).

\section{$\underline{\text { RDSS Vulnerability Approach }}$}

The likelihood of contaminants moving through the vadose zone was determined by developing a method, RDSS. The RDSS method was developed by combining relevant vulnerability parameters of DRASTIC (Depth to water table, Net Recharge, Aquifer media, Soil media, Topography, Impact of vadose zone, and Hydraulic Conductivity), GOD (Groundwater occurrence, Overall lithology of aquifer or aquitard, and Depth to groundwater table), EPIK (Epikarst, Protective cover, Infiltration conditions and Karst network development), SEEPAGE (System for Early Evaluation of Pollution potential of the Agricultural Groundwater Environment), COP (Flow Concentration, Overlying layers and Precipitation) and SINTACS (Soggiacenza (aquifer depth), Infiltrazione (Seepage water input), Non saturo (Unsaturated zone features; grain size, texture, mineral composition, faulting and karstification), Tipologiadellacopertura (Soil type), Acquifero (Hydrogeological characteristics of aquifer), Conducibilitá (Aquifer hydraulic conductivity), Superficietopografica (Roughness of land surface)). The inclusion of these methods was solely to acknowledge relevant parameters, although all approaches are not completely valid (e.g. EPIK).

RDSS evaluates the vadose zone as a pathway for pollutants by using the following four parameters: Recharge, Depth to water table, Soil type and Slope. The results obtained were presented using ArcGIS 9.3.1.

Recharge (R) was estimated using the Chloride Mass Balance (CMB) method. According to Wood (1999), CMB is based on the assumptions that chloride is sourced solely from the precipitation, that it remains conservative throughout the system, that the flux is temporally constant and that chloride is not recycled or concentrated within the aquifer. Recharge can be calculated using the relationship shown in Equation 1 (e.g. Witthüser et al. 2011) as a function of total recharge $\left(R_{T}, \mathrm{~mm} / \mathrm{a}\right)$, total atmospheric chloride deposition $(T D, \mathrm{mg} / \mathrm{l})$, mean annual precipitation 
$(M A P, \mathrm{~mm} / \mathrm{a})$ and mean annual chloride from groundwater $\left(\mathrm{Cl}_{g w}, \mathrm{mg} / \mathrm{l}\right)$. The total atmospheric chloride deposition (TD) and mean annual choride from groundwater data were obtained from the Department of Water Affairs and data for mean annual precipitation from the South African Weather Service.

$$
R_{T}=\frac{T D \times M A P}{C l_{g w}}
$$

\section{Equation 1}

Depth to Water Table (D) was measured by means of dipmeter and - where boreholes were inaccessible - historical data were included.

Soil Type (S) relates to the seepage behaviour of the site materials and was determined via infiltration and percolation testing. A double ring infiltrometer (DRI) in accordance with the method of Jenn et al., (2007) was used in order to determine infiltration as the change in head in the central ring over the time required for this drop in water level to take place. The percolation test was conducted in accordance to the South African National Standards (SANS) 10252-2:1993 where the percolation rate $(\mathrm{mm} / \mathrm{h})$ is once again calculated as the distance of infiltration divided by the time required for this drop in water level. All field values were converted to hydraulic conductivity following Darcy's law under the assumption that all tests have been repeated enough consecutive times to sufficiently presoak the site soils. The last tests conducted were used in the calculation of hydraulic conductivity.

Slope (S) is governed by topographical gradients and were generated from Digital Elevation Method (DEM) measurements on topographic maps at a scale of 1:50 000 using ESRI ArcGIS 9.3.1 software.

The four parameters were combined using overlays operations in ArcGIS 9.3.1. Overlays involve combining spatial and attribute data from two or more spatial data layers and are among the most common and powerful spatial data operations (Bolstad, 2005). An overlay operation requires that data layers use a common coordinate system. In this study, the South African standard for geographic coordinate systems, WGS 1984, was used in all maps and was projected to WGS 1984 Universal Transverse Mercator 36S. The polygons shapefiles were converted into raster using the conversion tool. The raster data were then reclassified using the reclassify tool in the spatial analyst tool, which assigns output values dependent on the specific input values (Bolstad, 2005). The rasters were reclassified as shown in Table 1. 
Table 1: Reclassification of rasters.

\begin{tabular}{|l|l|l|l|}
\hline Slope & Soil type & Recharge & Water level \\
\hline 0 (low) & 0 (low) & $0($ low $)$ & 0 (deep) \\
$<9.303^{\circ}$ & $<0.0000807 \mathrm{~m} / \mathrm{s}$ & $<20 \mathrm{~mm} / \mathrm{a}$ & $>35 \mathrm{~m}$ \\
\hline 1 (gentle) & 1 (intermediate) & 1 (intermediate) & 1 (intermediate) \\
$9.303-18.606^{\circ}$ & $0.0000807-0.000162 \mathrm{~m} / \mathrm{s}$ & $20-40 \mathrm{~mm} / \mathrm{a}$ & $17-35 \mathrm{~m}$ \\
\hline $2($ steep) & $2($ high) & $2($ high $)$ & $2($ shallow) \\
$>18.606^{\circ}$ & $>0.000162 \mathrm{~m} / \mathrm{s}$ & $>40 \mathrm{~mm} / \mathrm{a}$ & $<17 \mathrm{~m}$ \\
\hline
\end{tabular}

There are three raster overlay methods, viz. Weighted Sum, Weighted Overlay and Raster Calculator. After reclassification, the four parameters were evaluated in all of these overlay methods to produce the vulnerability maps for $\mathrm{B} 81 \mathrm{G}$ and $\mathrm{B} 82 \mathrm{D}$.

\section{Results}

The parameter maps reclassified to low, medium and high influence on aquifer vulnerability as per Table1 is shown in Figure 2 and the derivation of the maps is discussed below.

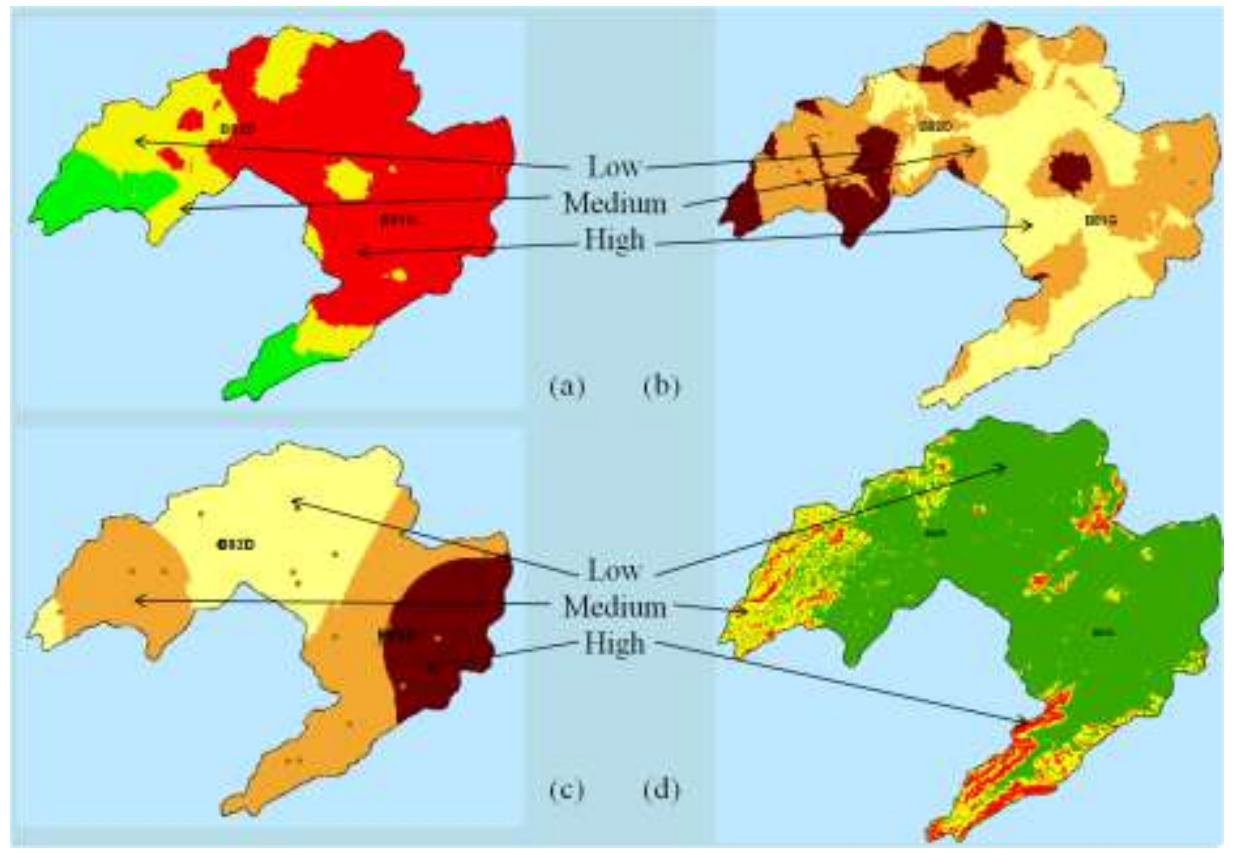

Figure 2.(a) Recharge $R$, (b) Depth to water table $D$, (c) Soil Type $S$ and (d) Slope $S$ with low, medium and high potential influence on aquifer vulnerability. 


\section{$\underline{\text { Recharge }}$}

Total annual recharge is averaged over the catchment area and was calculated as follows:

- Total Recharge for Molototsi Quaternary Catchment: $19.621 \mathrm{~mm} / \mathrm{a}$.

- Total Recharge for Middle Letaba Quaternary Catchment: 19.749 mm/a

The calculated recharge was analysed using ArcGIS. Cut-off value was implemented. The highest emperical value determined in recharge analysis was $83.019 \mathrm{~mm} / \mathrm{a}$. Any value $<20 \mathrm{~mm} / \mathrm{a}$ was regarded as low recharge (low influence on vulnerability); 20 to $40 \mathrm{~mm} / \mathrm{a}$ was regarded as intermediate recharge (medium); and greater than 40 $\mathrm{mm} / \mathrm{a}$ was regarded as high recharge (high). The results obtained show low recharge of $<20 \mathrm{~mm} / \mathrm{a}$ in the upper part of Molototsi and Middle Letaba quaternary catchments. Intermediate recharge of between $20-40 \mathrm{~mm} / \mathrm{a}$ was obtained in the lower part of Molototsi and Middle Letaba quaternary catchments as well as small portions in the upper part of both Molototsi and Middle Letaba quaternary catchments. High recharge of $>40 \mathrm{~mm} / \mathrm{a}$ was obtained in the lower part of both Molototsi and Middle Letaba quaternary catchments.

\section{Depth to Water Table}

The depth to the water table for Molototsi and Middle Letaba quaternary catchments was measured in the field. For inaccessible (sealed) boreholes more data was requested from GPM Consulting Company. The data were represented in ArcGIS. A cut-off value was implemented and the highest emperical value determined in depth to water level analysis was $70.43 \mathrm{~m}$. $35 \mathrm{~m}$ was regarded as a suitable cut-off. Any value $<17 \mathrm{~m}$ was regarded as shallow depth to water level (high influence on vulnerability); 17 - $35 \mathrm{~m}$ was regarded as intermediate (medium) and $>35 \mathrm{~m}$ was regarded as deep (low). The results obtained show shallow depth to water level of $<17 \mathrm{~m}$ on the lower part of B81G and the upper part of both B82D and B81G. Intermediate depth to water level of between 17 $35 \mathrm{~m}$ was revealed on the upper and small portion on the lower part of $\mathrm{B} 81 \mathrm{G}$, as well as the lower and upper parts of B82D. Deep depth to water level of $>35 \mathrm{~m}$ was reveled on the lower part of B82D, and the upper part of both $\mathrm{B} 81 \mathrm{G}$ and B82D.

\section{$\underline{\text { Soil Type }}$}

The results obtained from infiltration and percolation tests yielded a highest emperical value determined in soil type analysis of $0.000323 \mathrm{~m} / \mathrm{s}$ and therefore a value of $0.000162 \mathrm{~m} / \mathrm{s}$ was regarded as a suitable cut-off. Any value < $0.0000807 \mathrm{~m} / \mathrm{s}$ was regarded as low influence of soil type due to low hydraulic conductivity (low), $0.0000807-$ 
$0.000162 \mathrm{~m} / \mathrm{s}$ was regarded as intermediate (medium) and $>0.000162 \mathrm{~m} / \mathrm{s}$ was regarded as high. The results obtained shows that Middle Letaba quaternary catchment (B82D) is dominated by low conductivity soil type (1.28 $\left.1.85 \times 10^{-4} \mathrm{~m} / \mathrm{s}\right)$ with intermediate values $\left(1.85-2.41 \times 10^{-4} \mathrm{~m} / \mathrm{s}\right)$ revealed towards the lower part of Middle Letaba quaternary catchment (B82D). Molototsi quaternary catchment $(\mathrm{B} 81 \mathrm{G})$ is dominated by intermediate values (1.85 $\left.2.41 \times 10^{-4} \mathrm{~m} / \mathrm{s}\right)$ with high values $\left(2.41-3.23 \times 10^{-4} \mathrm{~m} / \mathrm{s}\right)$ shown on the upper part of Molototsi quaternary catchments (B81G).

$\underline{\text { Slope }}$

The slope was analysed using ArcGIS and a cut-off value was implemented. The highest emperical value determined in slope analysis was $37.213^{\circ}$ and therefore a value of $18.606^{\circ}$ was regarded as a suitable cut-off. Any value $<9.303^{\circ}$ was regarded as a low (shallow) slope; $9.303^{\circ}-18.606^{\circ}$ was regarded as medium (gentle) and > $18.606^{\circ}$ was regarded as high (steep). The results obtained show that both Molototsi (B81G) and Middle Letaba (B82D) quaternary catchments are dominated by low slope of $<9.303^{\circ}$. However, steep slopes were revealed on the lower parts of both Molototsi (B81G) and Middle Letaba (B82D) quaternary catchments. Similarly, gentle slope of between $9.303^{\circ}$ to $18.606^{\circ}$ was revealed on the lower parts of both Molototsi (B81G) and Middle Letaba (B82D) quaternary catchments. Some portions on the upper parts of both Molototsi (B81G) and Middle Letaba (B82D) quaternary catchments showed both steep and gentle slopes.

\section{The Aquifer Vulnerability of B81G and B82D}

The aquifer vulnerability of B81G and B82D was analysed using three overlay methods which are Weighted Sum, Weighted Overlay, and Raster Calculator ( Figure 5, 6, and 7). Parameter ranges as discussed were employed under the assumption that (a) rapid recharge will transport contaminant to the phreatic surface more rapidly, notably as recharge is generally not excessisively high as to serve as dilution of contaminants; (b) deeper groundwater will be more protected from groundwater(meaning not clear); (c) soil types of high conductivity will transport contaminanted water more rapidly; and (d) steep slopes will induce runoff, protecting groundwater, whereas gentle soils will induce infiltration. 
The Weighted Sum Aquifer Vulnerability Results

In order to verify the accuracy for the results, the analysis was undertaken considering different scenarios. Different scenarios were considered in order to address the influence of different weights for different parameters on the final vulnerability map. Table 2 indicates scenarios for aquifer vulnerability using Weighted Sum tool. Scenario B was chosen as the one which can best represent the aquifer vulnerability of B81G and B82D.

Table 2: Scenarios for aquifer vulnerability using Weighted Sum in B81G and B82D.

\begin{tabular}{|c|c|c|c|c|}
\hline Scenario & \multicolumn{4}{|c|}{ Weights of influence $=1$} \\
\hline & Recharge (R) & Depth to water table (D) & Soil type (S) & Slope (S) \\
\hline A & 0.25 & 0.25 & 0.25 & 0.25 \\
\hline B & 0.30 & 0.40 & 0.20 & 0.10 \\
\hline C & 0.15 & 0.40 & 0.30 & 0.15 \\
\hline D & 0.40 & 0.25 & 0.25 & 0.10 \\
\hline
\end{tabular}

Figure 3 reveals the aquifer vulnerability in B81G and B82D. The analysis was undertaken using the Weighted Sum tool and considering scenario B (Table 2). The cell values of each input raster (R, D, S, S) were multiplied by its raster's weight as assigned. The resulting cell values were added to produce the final output raster. The results obtained were classified into low, intermediate and high vulnerability. 


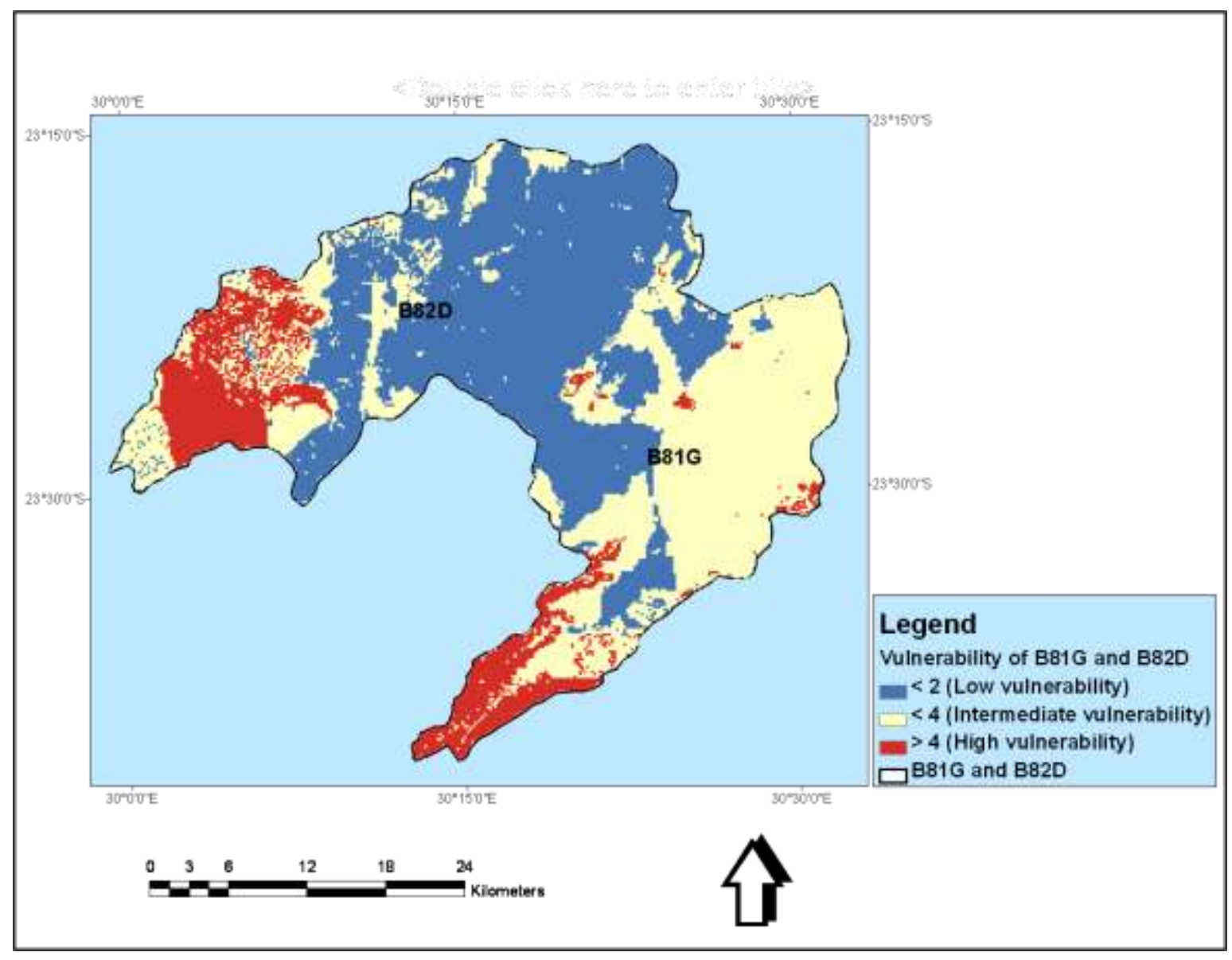

Figure 3: The aquifer vulnerability map for B81G and B82D analysed using Weighted Sum (scenario B).

The Weighted Overlay Aquifer Vulnerability Results

As with Weighted Sum, the Weighted Overlay tool was used to analyse the aquifer vulnerability of Molototsi (B81G) and Middle Letaba (B82D) quaternary catchments. The analysis was undertaken in order to verify the accuracy of the results obtained when using weighted Sum and considering different scenarios (Table 3). 
Table 3: Scenarios for aquifer vulnerability using Weighted Overlay in B81G and B82D.

\begin{tabular}{|l|l|l|l|l|l|}
\hline Scenario & \multicolumn{5}{l}{ Percentage of influence $=100 \%$} \\
\hline & Recharge & Depth to water table & Soil type & Slope & Scale \\
\hline A & $25 \%$ & $25 \%$ & $25 \%$ & $25 \%$ & 1 to 3 by 1 \\
\hline B & $30 \%$ & $35 \%$ & $20 \%$ & $15 \%$ & 1 to 3 by 1 \\
\hline C & $15 \%$ & $40 \%$ & $30 \%$ & $15 \%$ & 1 to 3 by 1 \\
\hline D & $10 \%$ & $40 \%$ & $40 \%$ & $10 \%$ & 1 to 3 by 1 \\
\hline
\end{tabular}

Scenario A is considered most representative and the aquifer vulnerability is shown in Figure 4. The analysis was undertaken using Weighted Overlay tool with $25 \%$ of influence assigned in each raster (scenario A, Table 3) within a scale of 1 to 3 by 1 . The cell values of each input raster (R, D, S, S) were multiplied by the $25 \%$ of influence and the resulting cell values were added to produce the final output raster.

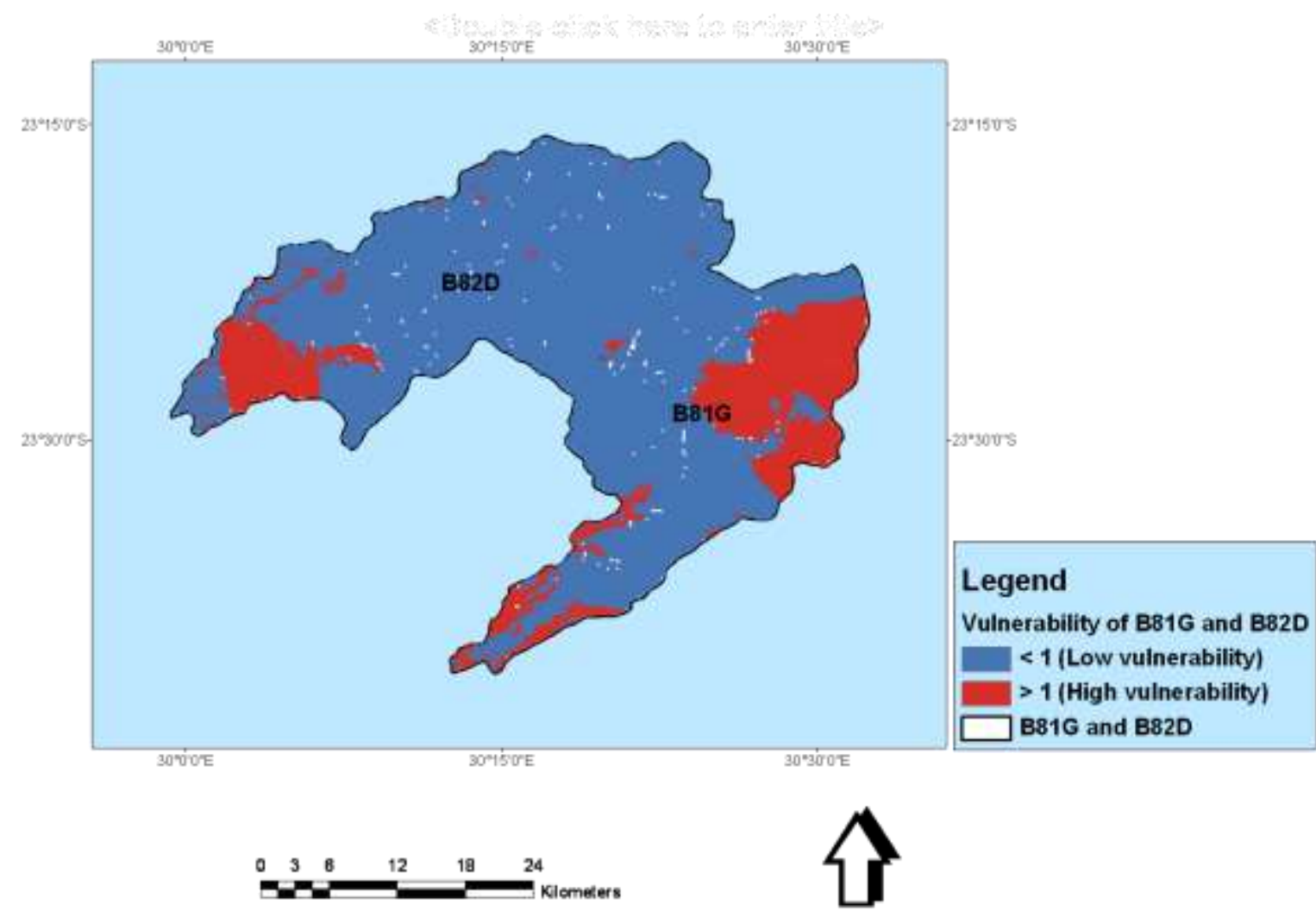

Figure 6: The aquifer vulnerability of B81G and B82D using Weighted Overlay (scenario A). 
The Raster Calculator Aquifer Vulnerability Results

Figure 5 depicts the aquifer vulnerability in the Molototsi (B81G) and Middle Letaba (B82D) quaternary catchments. In order to verify the accuracy of the results obtained when using Weighted Overlay and Weighted Sum, the Raster Calculator tool was used to perform the same task. The Map Algebra expression for recharge, depth to water level, soil type and slope was created by combining the rasters for these same parameters to produce the output raster. Unlike Weighted Sum and Weighted Overlay, the Raster Calculator does not assign weights to parameters, but rather works by generating an equation. The vulnerability map was classified into low, intermediate and high vulnerability.

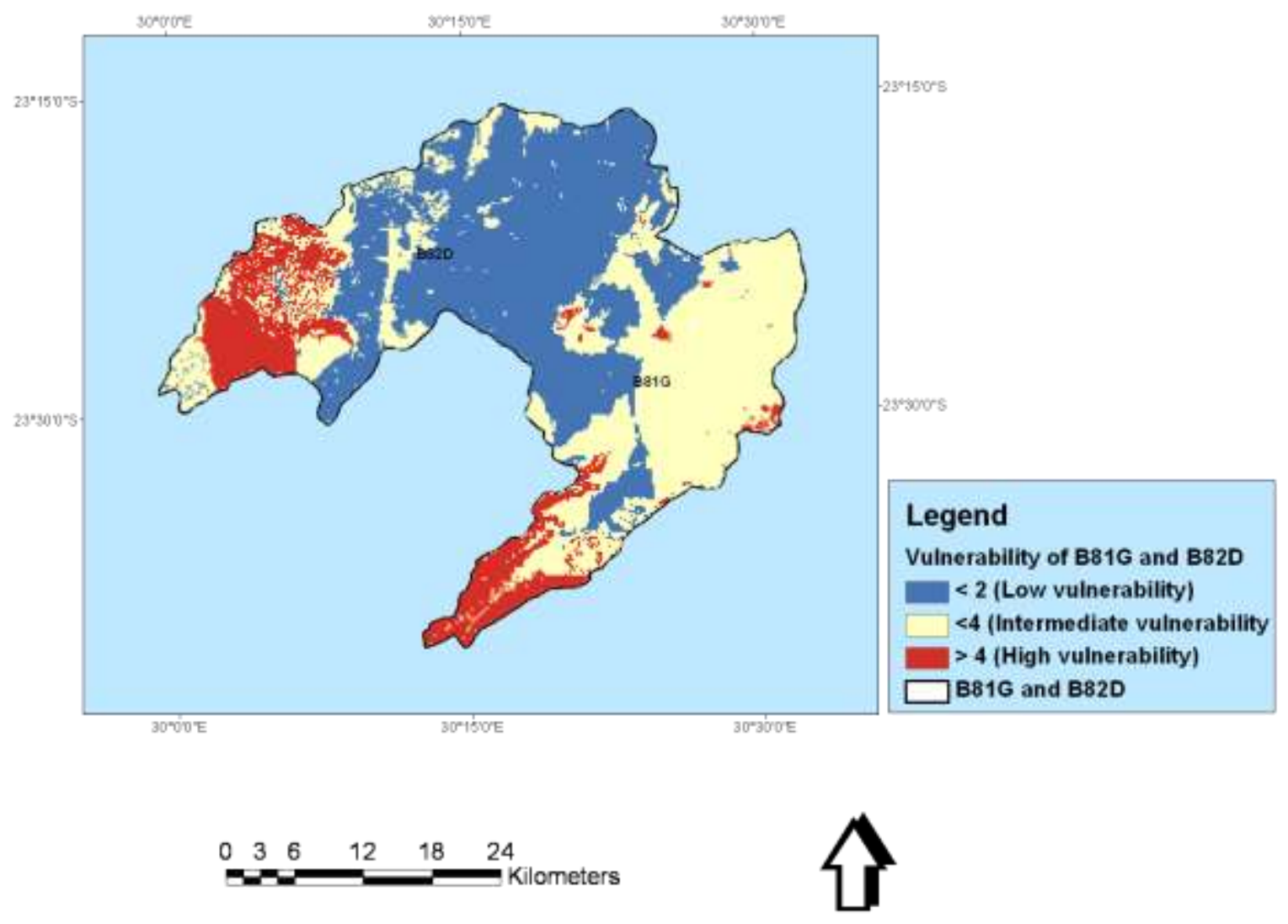

Figure 7: The aquifer vulnerability of B81G and B82D analysed using Raster Calculator. 


\section{Discussion and Conclusions}

\section{Aquifer Vulnerability Analysis using Weighted Sum Tool}

The results obtained from the four scenarios when using Weighted Sum were similar. High aquifer vulnerability was revealed from all scenarios on the lower parts of both Molototsi and Middle Letaba quaternary catchments. For scenarios $\mathrm{B}$ and $\mathrm{C}$, high vulnerability was revealed on the upper east of Molototsi quaternary catchment. The northern part of Middle Letaba quaternary catchment showed intermediate vulnerability in all the four scenarios. In all four scenarios intermediate vulnerability extended from the lower towards the upper part of Molototsi. Low vulnerability was revealed on the upper part of Middle Letaba quaternary catchments from all the scenarios.

Scenario B was chosen as the one which can best represent the aquifer vulnerability of Molototsi and Middle Letaba quaternary catchments, showing the clearest difference in vulnerability. D (depth to water level) carries the most weight here and subsequently influenced the resulting aquifer vulnerability map most and accentuated zones of differing vulnerability. The depth to the groundwater table for this particular study is more variable that the other parameters with limited variation in the values obtained for the soil types and recharge.

\section{Aquifer Vulnerability Analysis using Weighted Overlay Tool}

From all the four scenarios high aquifer vulnerability was revealed on the lower part of both Molototsi and Middle Letaba quaternary catchments. However, high vulnerability was also revealed on the upper east of Molototsi quaternary catchments. All the four scenarios showed that Molototsi and Middle Letaba are dominated by low vulnerability. Scenario A accentuated the variability in vulnerability best and is also convenient in equal weights for all four parameters.

\section{Aquifer Vulnerability Analysis using Raster Calculator Tool}

The results obtained when using Raster Calculator were similar to those obtained when using Weighted Sum (scenario A). High aquifer vulnerability was revealed on the lower parts of both B81G and B82D. B81G is dominated by intermediate vulnerability, the vulnerability extended from the lower towards the upper part of the 
quaternary catchment. However B82D showed intermediate vulnerability on the lower and some portions on the upper part of the quaternary catchment. B82D is dominated by low vulnerability. The vulnerability extended from the lower part of B82D towards the upper part of B81G.

\section{Evaluation of Parameters}

The geology of Molototsi and Middle Letaba quaternary catchments is dominated by gneisses. Gneisses are a common and widely distributed type of rock formed by high-grade regional metamorphic processes from preexisting formations that were originally either igneous or sedimentary rocks. Gneissic rocks are usually medium to coarse grained, foliated and largely recrystallized with varying degrees of mica and other platy minerals. The absence of chlorite or other chlorine-bearing minerals in gneisses makes the chloride mass balance method applicable for recharge estimation (e.g. DEAT 2009).

Depth to water table is not static; water tables are variable and fluctuate over time with typical rise in water table resulting from high rainfall events (e.g. Leduc et al. 1997; Zhang and Schilling 2006). Despite the variation, data have been - where possible - collected or filtered for the same seasons and are therefore reliable for this study.

According Department of Environmental Protection (2006) infiltration and percolation tests should not be conducted in the rain or within 24 hours of significant rainfall events or when the temperature is below freezing. The infiltration, percolation, and hydraulic conductivity in the area of study were undertaken considering saturation from extensive presoaking which might be simulated as extensive rainfall and are therefore considered applicable.

According to Toutin (2002) the ability to carry out realistic terrain analyses is limited primarily by the quality of DEM applied in terms of the accuracy and distribution of the elevation point used to interpolate the DEM, the interpolation logarithm used to generate a continuous DEM, and the chosen grid cell size. According to Kjeldsen $e t$ al., (2002) the larger the grid size, the more the DEM fail to represent steeper slopes. The smaller the grid size the higher is the catchment proportion of zero percent slope and steep slopes. According to Helmschrot (1999) the official DEM of South Africa has a grid size of $200 \mathrm{~m}$, which is not sufficient for slope analysis on a regional scale. Hence a raster based DEM $_{90}$ developed from Shuttle Radar Topography Mission (SRTM) with a grid size of $90 \mathrm{~m} \mathrm{x}$ $90 \mathrm{~m}$ was used for slope analysis in Molototsi and Middle Letaba quaternary catchments. Reducing the grid size makes the results obtained for slope analysis reliable. 
The method RDSS works by overlaying the parameters (recharge, depth to water level, soil type, and slope). When overlain, areas where these values are high will contribute to higher potential aquifer vulnerability. Recharge, notably when not excessively high, is the principal vehicle for transporting contaminants to the water table and increasing recharge increases the chances of contaminants reaching the water table. Depth to water level determines the depth of material through which contaminants must travel before reaching the aquifer and deeper groundwater tables will therefore be more protected. Soil type (the seepage behaviour of water) has a significant impact on the amount of recharge that can infiltrate into the ground, as well as the rate of potential percolation. When considering soil type, vertical heterogeneity can also be included to address the degree of protection of the aquifer. Topography helps control the likehood that pollutants will rather runoff on steep slopes or remain static long enough on shallow slopes to infiltrate.

Similar results with minor variations were determined using four scenarios each of Weighted Sum and Weighted Overlay, as well as the Raster Calculator. Optimal scenarios were selected for each to optimise the weighting in order to obtain significant aquifer vulnerability maps.

With limited variation in recharge and soil type parameters, a greater weight on the depth to groundwater parameter aided in accentuating different zones of aquifer vulnerability. These adjustments will be necessary for other studies and will depend on tha available data and local conditions.

The value of the RDSS approach is the ready availability of parameters which are easy to measure and quantify, removing arbitrary index assumption of a wide range of parameters with varying degrees of screening. The evaluation of different methods and weighting scenarios yielded similar results based on the input data and the aquifer vulnerability maps compiled are considered applicable to the study area. Validation of the results by groundwater quality assessments are presently being considered.

\section{Acknowledgements}

The authors wish to thank the National Research Foundation (NRF) for co-funding this research. This work forms part of the project funded by the Water Research Commission (WRC) of South Africa (Report No.KV 243/10). 


\section{References}

Babiker IS, Mohamed MA, Hiyama T, Kato K (2005) A GIS-based DRASTIC Method for Assessing Aquifer Vulnerability in Kakamigahara Height, Gifu Prefecture, Central Japan. J Sci Tot Env345:127140.doi:10.1016/j.scitotenv.2004.11.005

Bolstad P (2005) Basic Spatial Analysis. In: GIS Fundamentals: A First Text on Geographic Information Systems, $2^{\text {nd }}$ edn. White Bear Lake, Minnesota, United States of America, pp324-355

Boulding JR, Ginn JS (2004) Ground Water and Vadose Zone Hydrology. In: Soil, Vadose Zone, and Ground-water Contamination: Practical Handbook of Assessment, Prevention and Remediation. $2^{\text {nd }}$ edn. London, New York, pp50

[DEAT] Department of Environmental Affairs and Tourism (2009). Environmental Management Framework for the Olifants and Letaba River Catchment Areas: Draft Report on the Status Quo, Opportunities, Constraints and the Desired State, Pretoria, South Africa, pp12

Department of Environmental Protection (2006).Pennsylvania Stormwater Best Management Practices Manual. Bureau of Watershed Management, 30(20), 437-443

Deming D (2002) Introduction to Hydrogeology. $1^{\text {st }}$ edn. New York, pp 468

Dippenaar, M. A., Van Rooy, J. L., Freese, R. and Makonto, O. T. (2010). Preliminary Vadose Zone Classification methodology (Molototsi and middle Letaba Quaternary Catchments). Water Research Commission. Report KV 243/10. Pretoria.

Dippenaar, M. A., Wittüser, K.T. and Van Rooy, J. L. (2009). Groundwater occurrence in Basement aquifers in Limpopo Province, South Africa: model-setting-scenario approach. Environmental Earth Science. 59:459-464. 
[DWAF] Department of Water Affairs and Forestry (2004). Internal Strategic Perspective: Luvuvhu/Letaba Water Management Area: Prepared by GobaMoahloli Keeve Steyn (Pty) Ltd in Association with Tlou and Matji, Golder Associates Africa and BKS on behalf of the Directorate: National Water Resource Planning. Department of Water Affairs and Forestry (South Africa) Report Number PWMA 02/000/00/0304.pp1-18

[DWAF] Van Vuuren, A.J., Jordaan, H., Van Der Walt, E. and Vanjaarveld, S. (2003). Luvuvhu and Letaba Water Management Area: Water Resource Situation Assessment. Department of Water Affairs and Forestry (South Africa), Report Number P/02000/00/0101. pp2-3.

Helmschrot, J (1999). Applications of Remote Sensing Data for Distributed Hydrological Modelling of Large Scale Afforested Areas in the Northern East Cape Province, South Africa. Session: Research and Management of Ecosystems and Natural Resources Including Forests, Germany, pp1-8

Jenn F, Knödel K, Liese M, Voigt H (2007) Precipitation. In: Knödel K, Lange G, Voigt HJ (ed) Environmental Geology: Handbook of Methods and Case Studies. Springer. Heidelberg. pp 652-653

Kjeldsen TR, Smithers JC, Schulze RE (2002)Regional Flood Frequency Analysis in Kwazulu-Natal Province, South Africa, Using the Index-Flood Method. J Hydrol225:194-211. PII:S 0022-1694(01)00520-0

Kröner A, Jaeckel P, Brandl G (2000) Single Zircon Ages for Felsic to Intermediate Rocks from the Pieterburg and Giyani Greenstone Belts and Bordering GranitoidOrthogneisses, Northern KaapvaalCraton, South Africa. J Afr Earth Sci30:773-793. PII:S 0899-5362(00)00052-X

Leduc C, Bromley J, Schroeter P (1997) Water Table Fluctuation and Recharge in Semi-Arid Climate: Some Results of the HAPEX-Sahel Hydrodynamic Survey (Niger), J Hydrol188: 123-138. PII: S 0022-1694(96)03156-3

Nyabeze WR, Mallory S, Hallowes J, Mwaka B, Sinha P (2007) Determining Operating Rules for the Letaba River System in South Africa Using three Methods. J PhyChem Earth32:1040-1049.doi: 10.1016/j.pce.2007.07.003 
Poehls, D.J. and Smith, G.J (2009). Encyclopedic Dictionary of Hydrogeology. In: Ganus, W.J., Hurst, R.W. and Smith, L. (ed), $1^{\text {st }}$ edn. London, UK. pp358

[SANS] South African National Standards. (1993) Code of practice: Water supply and drainage for buildings. Part 2:drainage installations for buildings. SABS 10252-2:1993.

Toutin, T. (2002). Review Article: Geometric Processing of Remote Sensing Images: Models, Algorithms and Methods. Int J Rem Sens25:1893-1924.doi:10.1080/0143116031000101611

Van Schalkwyk A, Vermaak JJG (2000) The Relationship between Geotechnical and Hydrogeological Properties of Residual Soils and Rocks in the Vadose Zone, Water Research Commission (South Africa), Report NO.701/1/11/

Witthüser KT, Holland M, Rossouw TG, Rambau E, Bumby AJ, Petzer KJ, Dennis I, Beekman H, van Rooy JL, Dippenaar M, de Wit M (2011) Determining Sustainable Yields of Potential Productive Well Fields in the Basement Aquifers of the Limpopo Province With Special Emphasis on the (WMA) and Luvuvhu/Letaba (WMA 2) Water Management Areas. Water Research Commission (South Africa) Project Number K5/1693/1, pp5

Wood, W.W. (1999). Use and Misuse of the Chloride-Mass Balance Method in Estimating Groundwater Recharge. Grw, 37 (1), 2-3. Doi.10.1111/j1745-6584.1999.tb00.

Zhang YK, Schilling KE (2006) Effects of Land Cover on Water Table, Soil Moisture, Evapotranspiration, and Groundwater Recharge: A Field Observation and Analysis. J Hyrol319: 328-338. doi:10.1016/j.jhydrol.2005.06. 